\title{
Trauma of External Genitalia by Firearm: Therapeutic Strategy and Result, about a Case at CHU-YO, Ouagadougou, Burkina Faso
}

\author{
Clôtaire Alexis Marie Kiemdiba Donega Yameogo, Brahima Kirakoya, Moussa Kaboré*, \\ Fasnéwindé A. Kaboré, Bienvenue D. Ky, Boukary Kabré, Barnabé Zango \\ Department of Urology, Yalgado Ouédraogo Teaching Hospital, Ouagadougou, Burkina Faso \\ Email: "kaborem391@yahoo.com
}

Received 7 February 2016; accepted 19 April 2016; published 22 April 2016

Copyright (C) 2016 by authors and Scientific Research Publishing Inc.

This work is licensed under the Creative Commons Attribution International License (CC BY). http://creativecommons.org/licenses/by/4.0/

(c) (i) Open Access

\begin{abstract}
Introduction: Ballistic traumas of the external genitalia are rare especially in civil practice. Emergency surgical exploration is the rule. Case Report: Mr. F.Y., 29 years old, a security agent, admitted to the Urological Emergency Unit of Yalgado Ouédraogo University Hospital of Ouagadougou for trauma of the penile and left purse by firearm. The clinical examination revealed a good hemodynamic status, bladder distension. A suprapubic catheterization was performed. We noted a transfixing and bleeding wound on the penile, and on the left purse which was edematous. The patient was admitted to the operation room 07 hours after trauma. Exploration found a total destruction of the left testicle classified grade 5 of the classification of the American Association of the Surgery of Trauma (AAST). We performed a left orchiectomy. There was a partial rupture of the ventral face of the penile urethra. We performed an end-to-end anastomosis on a Foley catheter $\mathrm{CH}$ 18. The Foley catheter was removed after two weeks. Urination was spontaneous without dysuria. Erections were painless and without kinking of penile. Conclusion: Open traumas of the external genitalia are rare and their treatment is an extreme surgical emergency.
\end{abstract}

\section{Keywords}

Trauma, External Genitalia, Firearms, Emergency

\section{Introduction}

Traumas of the external genitalia by firearms are extremely rare [1]. They mainly affect young population [1]

\footnotetext{
${ }^{*}$ Corresponding author.
}

How to cite this paper: Yameogo, C.A.M.K.D., Kirakoya, B., Kaboré, M., Kaboré, F.A., Ky, B.D., Kabré, B. and Zango, B. (2016) Trauma of External Genitalia by Firearm: Therapeutic Strategy and Result, about a Case at CHU-YO, Ouagadougou, Burkina Faso. Open Journal of Urology, 6, 63-66. http://dx.doi.org/10.4236/oju.2016.64012 
[2]. Injuries can be severe and complex. The time between injury and treatment is an important component of the subsequent functional outcome. Facing this lesional complexity, a question arises: should we immediately repair urethral and corpora cavernosa lesions? Two therapeutic approaches are opposed [3]. But the best approach is to consider the risks of infection and the importance of the defect [2]. We report a case to describe the lesion complexity and our therapeutic strategy. We obtained the informed consent from the patient for this study.

\section{Case Report}

Mr. F.Y., 29-year-old, a security agent, admitted to the urological emergency unit of Yalgado Ouédraogo University Hospital of Ouagadougou for trauma of the penile and left purse by firearm. During a brawl the patient had been knocked to the ground with reception on the left side of the body. The pistol of $9 \mathrm{~mm}$ he had in the left pocket of his trousers was actuated accidentally with reception of the projectile on the penile and the left purse. The patient was admitted 05 hours after the trauma. The clinical examination revealed a good hemodynamic status, bladder distension. A suprapubic catheterization was performed. We noted a transfixing and bleeding wound of the penile with urethral bleeding, a transfixing and bleeding wound on the left purse which was edematous (Figure 1). At the left purse painful swelling were noted. The left scrotal content was difficult to palpate. The patient was admitted to the operation room 07 hours after trauma. First we performed a longitudinal incision on the left purse. Exploration found a large hematoma that we evacuated. There was a total destruction of the left testicle classified grade 5 of the classification of the American association of the Surgery of trauma (AAST) (Figure 2). We performed a left orchiectomy. Secondly we performed a coronal incision. Undressing of the penile noted a partial rupture of the ventral side of the penile urethra (Figure 3). The albuginea of the corpora cavernosa is intact. We performed an end-to-end anastomosis on a Foley catheter $\mathrm{CH}$ 18. The supra-pubic catheter was removed just at the end of the intervention. Medical treatment with tetanus vaccine, tetanus antitoxin and antibiotics was administered. The Foley catheter was removed after two weeks. At the removal of the catheter, urination was spontaneous without dysuria. Erections were painless and without kinking of penile (Figure 4). The patient was seen after six months. Urination and erections were normal.

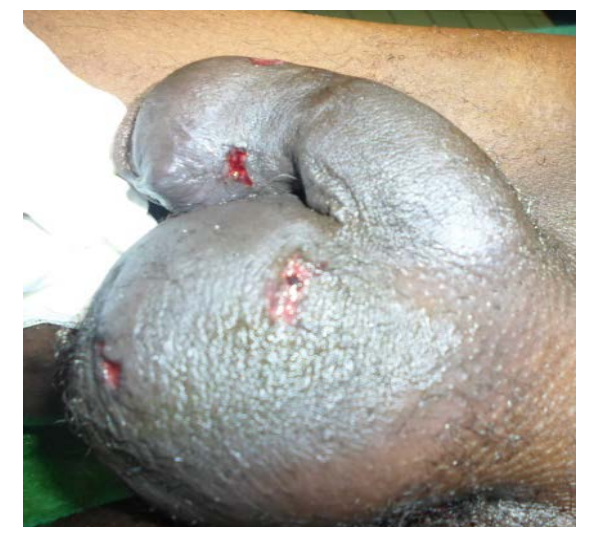

Figure 1. Inlet and outlet.

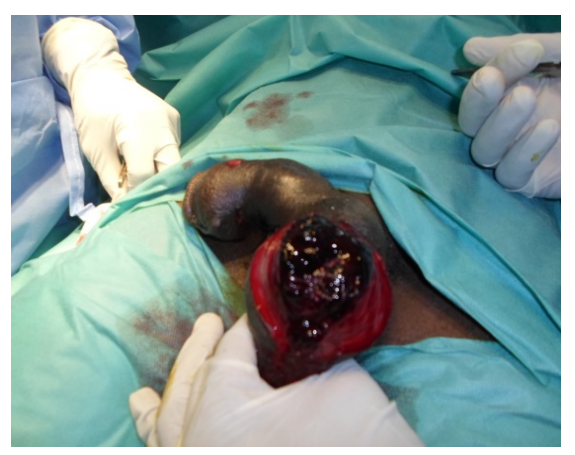

Figure 2. Necrotic left testicle. 


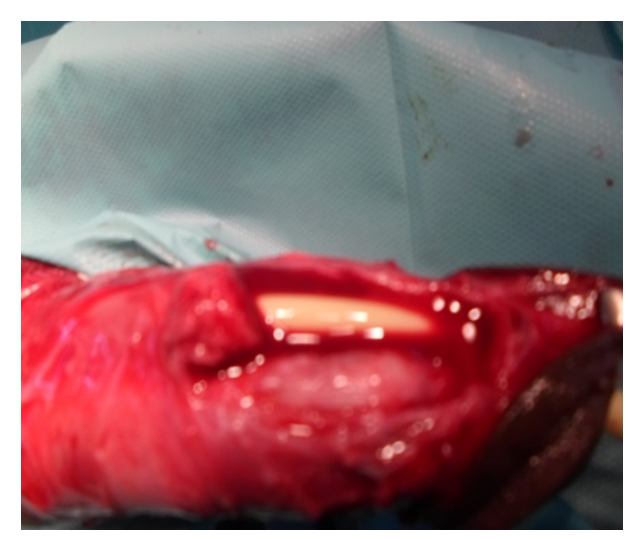

Figure 3. Rupture of the urethra.

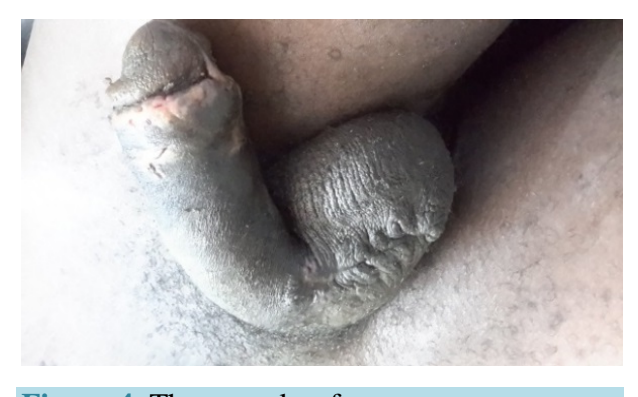

Figure 4. Three weeks after.

\section{Discussion}

Genitalia injuries by firearms constitute a surgical emergency. These injuries are rare, especially in civil practice. This scarcity is highlighted in most published series. In USA, after an experience of 20 years Simhan reported 97 cases of scrotal gunshot wound. In Sénégal, BAH et al. reported six cases in 04 years [1]. In Burkina Faso, Kambou T. et al. reported no cases of ballistic trauma genitalia over a period of eight years [4]. However, the incidence of all the injuries by firearms increases every year. In Burkina Faso, PWH Dakouré et al. reported 39 cases of ballistic trauma over a period of 18 months without any cases of external genitalia trauma [5]. The increased incidence of ballistic trauma could find an explanation in the proliferation of small arms and intensification of crime. The corollary of this great crime is the exponential increase in security companies employing workers who are not highly trained in handling weapons adding a risk factor of ballistic trauma. Clinically injury of the anterior urethra was suspected if there is an urethral bleeding and acute urinary retention. The urethral bleeding occurs in at least $75 \%$ of cases of trauma of the anterior urethra. It is practically constant for some authors [6]. The absence of a rupture of the corpora cavernosa in our case could be explained by the tangential trajectory of the projectile. The surgical management of open external genitalia trauma should be done urgently [7]. In cases of ballistic trauma of the external genitalia, a surgical treatment before the first six hours remains the ideal. Beyond six hours, tissue necrosis appears and threatens the conservative treatment. This is the case of our patient who was admitted to the operation room 07 hours after the trauma and in whom it was performed a left orchiectomy. Mianne D. et al. have reported an orchiectomy rate of $50 \%$ to $60 \%$ in war practice [2] [8]. The urethral injury was repaired in our case by an end to end anastomosis through a disrobing of the penile. Regarding the urethral injury we have two strategies: while some adopt immediate repair as Husmann DA [9], others rather advocate a two-stage treatment because of the risk of infection [3]. The best attitude is to consider the risks of infection and the importance of the defect [2]. In our patient there was no loss of urethral substance. This allowed us to perform urethroplasty in a time. We think that the complete disrobing of the penis is the best approach to treat penile lesions. That takes on its sense especially if it is a ballistic trauma because the trajectory of the projectile is unpredictable. To avoid missing a lesion of the corpora cavernosa a complete undressing of the penile must be done. This prevents erectile dysfunction and a possible forensic problem. The projectile trajectory is unpredictable and lesion assessment is exhaustive in intraoperative. The early treatment determines 
functional outcomes in trauma genitalia. Disruption of semen analysis after purse trauma with testicular damage is almost constant in most published series. It would be due to the production of anti-sperm antibodies or testicular atrophy [10]-[12].

\section{Conclusion}

Open injuries of external genitalia are a urological emergency but above andrological. An early treatment can improve functional and esthetic outcome. The best attitude is to consider the risks of infection and the importance of the defect. The complete undressing of the penile is the best way to treat urethral lesions and those of the corpora cavernosa.

\section{Conflict of Interests}

None.

\section{References}

[1] Kpatcha, T.M., Tengue, K., Tchangai, B., Kanassoua, K., Botcho, G., Sikpa, K., Anoukoum, T. and Dosseh, E.D. (2014) Lésions des organes génitaux externes par arme à feu: A propos d'une observation. Uro'Andro, 1.

[2] Bah, I., Diallo, A.B., Diao, B., N’doye, A.K., Gueye, S.M., Diallo, M.B. and Diagne, B.A. (2006) Les lésions des organes génitaux externes par arme à feu: A propos de six observations à l'hôpital A. Le Dantec Dakar, Senegal. African Journal of Urology, 12, 55-59.

[3] Mahamat, M.A., Sougui, S., Ouchemi, C., Ngaringuem, O., Jalloh, M., Niang, L. and Gueye, S.M. (2015) Severe External Genitalia Lesion by Firearm: A Case Report. Open Journal of Urology, 5, 188-191. http://dx.doi.org/10.4236/oju.2015.510030

[4] Kambout, O.A., Zare, C., Ouattara, A.M., Pare, A.K. and Sanon, B.G. (2014) Traumatismes urogénitaux: Profil épidémiologique et aspects lésionnels au centre hospitalier universitaire Sourou SANON de Bobo dioulasso (Burkina Faso). Uro'Andro, 1.

[5] Dakouré, P.W.H., Abalo, A.G., Sanon, B.G., Da, S.C., Kambou, T. and Ouédraogo, R.K. (2011) Traumatismes balistiques Au CHU de Bobo-Dioulasso (Burkina Faso): A Propos De 39 Cas. Journal de la Recherche Scientifique de l'Université de Lomé, 13.

[6] Biserte, J. and Nivet, J. (2006) Traumatisme de l'urètre antérieur: Diagnostic et traitement. Annales d'Urologie, 40, 220-232. http://dx.doi.org/10.1016/j.anuro.2006.05.002

[7] Prunet, D. and Bouchot, O. (1996) Les traumatismes du pénis. Progrès en Urologie, 6, 987-993.

[8] Mianne, D., Guillotreau, J. and Segent, H. (1997) Les plaies périnéales en pratique de guerre. Annale d’Urologie, 31, 235-332.

[9] Husmann, D.A., Boone, T.B. and Wilson, W.T. (1993) Management of Low Velocity Gunshot Wounds to the Anterior Urethra: The Role of Primary Repair versus Urinary Diversion Only. The Journal of Urology, 150, 70-72.

[10] Benchekroun, A., Iken, A., Kasmaoui, E., Jira, H., Nouini, Y., Lachkar, A. and Faik, M. (2001) Traumatisme des bourses. À propos de 40 cas. Annales $d$ Urologie, 35, 349-352. http://dx.doi.org/10.1016/S0003-4401(01)00058-4

[11] Diao, B., N’doye, K., Fall, P.A., Berthe, H., Ondo, C.Z., Niang, L., Ba, M. and Diagne, B.A. (2007) Traumatisme des bourses: A propos de 14 observations. African Journal of Urology, 13, 151-156.

[12] Culty, T. and Ravery, V. (2004) Traumatismes Scrotaux: Stratégie de prise en charge. Annales d'Urologie-EMC Urologie, 40, 117-125. http://dx.doi.org/10.1016/j.anuro.2006.01.008 